\title{
GENEZA I EWOLUCJA SZAT LITURGICZNYCH: ORNAT, DALMATYKA I KAPA. ZABYTKOWE SZATY LITURGICZNE BAZYLIKI MNIEJSZEJ W SIERADZU
}

Streszczenie. Pomimo rozpowszechnionej ochrony zabytków, wciąż mało miejsca poświęca się szatom liturgicznym. Uszyte ręcznie z haftami wykonanymi z dużą precyzją, zamknięte w szafach zakrystii często są skazane na zapomnienie i powolną, postępującą destrukcję. W opracowaniu przywołuje się genezę i rozwój ornatu, dalmatyki i kapy, będących widzialną oprawą celebracji liturgicznych. Długa historia zmian zachodzących w ich kroju i zdobieniu ma za zadanie uwrażliwienie na ochronę tych wyjątkowych obiektów, będących widzialnymi dobrami kultury regionów, w których były używane. Punktem wyjścia do opracowania niniejszego artykułu było ponowne skatalogowanie przez dr Ewę Andrzejewską zbioru szat liturgicznych znajdujących się w Bazylice Mniejszej w Sieradzu. W zakończeniu artykułu zamieszczono inwentarz obiektów z uwzględnieniem ich numeru rejestracji bez opisu, który (bardzo obszerny) znajduje się na poszczególnych kartach ewidencyjnych zabytku ruchomego.

Słowa klucze: ornat; dalmatyka; kapa; Sieradz; szaty liturgiczne; liturgia.

Abstract. Genesis and evolution of liturgical vestments: chasuble, dalmatic and cape. Historical liturgical vestments collected at the minor basilica in Sieradz. Despite the widespread protection of monuments, there is still little space devoted to liturgical vestments as movable historic objects. Hand-sewn with embroidery made with 
high precision, closed in sacristy cabinets they are often doomed to oblivion and slow, progressive destruction. The study refers to the genesis and development of chasuble, dalmatics and cape, which are a visible frame of liturgical celebrations. The long history of changes taking place in their form and decoration is intended to sensitize the protection of these unique objects, which are visible cultural goods of the regions in which they were used. The starting point for the present text of this article was the re-cataloging of a collection of liturgical vestments by Dr. Ewa Andrzejewska at the Minor Basilica in Sieradz. At the end of the article, an inventory of objects is included, taking into account their registration number without a very extensive description, which is provided on individual record cards of a movable cultural property.

Key words: chasuble; dalmatic; cape; Sieradz; liturgical vestments; liturgy.

Dyskusja nad genezą szat liturgicznych mimo upływających lat i prowadzonych studiów jest wciąż otwarta. Jak zauważa M. Wendland, istnieją dwie teorie. Pierwsza, opierając się na Piśmie Świętym, zakłada, że pierwowzorem szat chrześcijańskich były te używane przez lewitów. Druga, której przedstawicielem jest J. Braun, twierdzi, że szaty kapłanów chrześcijańskich są wynikiem ewolucji ubrań codziennego użytku obywateli rzymskich z I i II wieku n.e. S. Piccolo Paci zwraca uwagę, że wśród uczonych nie brakuje opinii o bliskich relacjach lub wręcz zależności między chrześcijańskim strojem liturgicznym a tym starotestamentalnym ${ }^{1}$. Ze względu na znikome źródła piśmienne dotyczące pierwszych szat używanych podczas sprawowania liturgii pozostaje opieranie się na ikonografii występującej w katakumbach, gdzie kapłani przedstawieni są w strojach niczym nieróżniących się od tych noszonych przez wiernych świeckich ${ }^{2}$.

Ze względu na rodzaj zabytkowych szat liturgicznych przechowywanych w bazylice w Sieradzu niniejszy artykuł ograniczy się do opisu ewolucji szat wierzchnich: ornatu, dalmatyki i kapy.

1 Por. S. Piccolo Paci, Storia delle vesti liturgiche. Forma, immagine e funzione, Milano 2008, s. 32-33.

${ }^{2}$ Por. J. Wilpert, Le pitture nelle catacombe romane, Roma 1903, t. 1, s. 60n. 


\section{ORNAT - GENEZA I ROZWÓJ}

Do podstawowej, a zarazem najczcigodniejszej szaty liturgicznej, którą kapłan przywdziewa w trakcie trwania czynności liturgicznych, należy ornat ${ }^{3}$. Przez wieki przechodził on transformację zarówno pod względem formy, jak i ornamentów. Swymi początkami sięga kultury starożytnych cywilizacji Grecji i Rzymu. Pochodzi od phaenula ${ }^{4}$. Strój ten lekki, w formie okręgu z otworem na głowę był używany w czasie podróży i opadów deszczu ${ }^{5}$. Z wiekiem, paenula stała się ubiorem obowiązującym podczas przedstawień cyrkowych i teatralnych, a od IV wieku została wprowadzona do szat urzędowych, np. senatorskich, adwokackich oraz duchownych chrześcijańskich, jako szata sakralna. Wykonana z białej wełny i ozdobiona purpurowym clavi ${ }^{6}$ nosiła nazwę casula bądź planeta. Od niej pochodzi krój późniejszego ornatu

W tradycji chrześcijańskiej od IV wieku phaenula została uznana za ubranie wszystkich uczestników kultu, następnie z biegiem czasu stała się strojem właściwym dla sprawującego czynności liturgiczne ${ }^{8}$. Św. Paweł w Liście do Tymoteusza (2 Tym 4, 13) wspomina o opończy (paenula), prosząc o przyniesienie jej wraz z pergaminami. W owym płaszczu egzegeci upatrują źródła pierwotnej szaty liturgicznej ${ }^{9}$ Niektórzy sugerują,

3 Por. W. Głowa, Posługi i funkcje w zgromadzeniu liturgicznym, w: Mszał ksiegga życia chrześcijańskiego, red. B. Nadolskiego, Poznań 1986, s. 315-316.

${ }^{4}$ Por. A. Sorrentino, Sztuka przewodniczenia celebracjom liturgicznym. Praktyczne sugestie dla kapłanów, Kraków 2001, s. 176; A. M. Komornicka, Zagadki z Biblii, Tradycji i Kultury chrześcijańskiej, t. 1, Marki 2000, s. 248; S. Piccolo Paci, dz. cyt., s. 312.

${ }_{5}^{5}$ Niektórzy naukowcy uważają, że ten rodzaj płaszcza, przypominającego poncho, był czymś w rodzaju długiego drapowanego szala $\mathrm{z}$ otworami na ręce. Inni upatrują w nim rodzaju szerokiego płaszcza zarzucanego na togę. Por. F. Boucher, Historia mody. Dzieje ubiorów od czasów prehistorycznych do końca XX wieku, Warszawa [brw.], s. 99.

${ }^{6}$ M. Gutkowska-Rychlewska, Historia ubiorów, Wrocław-Warszawa-Kraków 1968, s. 863. „clavus, clavi, łac. to naramienny pionowy szlak purpury, utkany z całym ubiorem lub naszyty. Pierwotnie oznaka klasowa, [...] później wyłącznie dekoracyjne”.

7 Por. K. Konecki, Pochodzenie i rozwój szat liturgicznych, „Anamnesis” 13 (1997/1998), s. 52-53; M. Gutkowska-Rychlewska, dz. cyt., s. 79-86.

8 Por. A. Sorrentino, dz. cyt., s. 176.

9 Por. A. Nowowiejski, Wykład liturgii Kościoła Katolickiego, t. 2, Warszawa 1902, s. 5. 
że wyraz tutaj użyty oznacza raczej płótno do zawinięcia księgi ${ }^{10}$. Ornat do X wieku był szatą przeznaczoną dla wszystkich stopni duchowieństwa. W Ordines Romani można zauważyć lektorów, akolitów, subdiakonów i diakonów noszących ornaty ${ }^{11}$.

Jeszcze w XIII w. subdiakoni i diakoni w dni postu i pokuty przy Ofierze Mszy świętej zamiast tunicelli i dalmatyki go nosili, jako casulam plicatam [ornat zawinięty). [...] diakon przed [...] uroczystym odśpiewaniem Ewangelii zdejmował z siebie [...] casulam plicatam, lecz nie składał jej nigdzie, tylko zawijał w pas podłużny, i w takiej formie kładł na lewe ramię i zawiązywał pod prawą ręką, przy boku. ${ }^{12}$

Phaenula z czasem przybrała nazwę grecką - planety ( $\pi \lambda a v \eta \dot{\tau} \varsigma$ ), co miało symbolizować planetę obracająca się wokół słońca, tak jak szata wokół ciała celebransa. Inną nazwą ornatu była casula (od łac. parva casa - mały domek). Jako pierwszy nazwy tej używa św. Izydor sewilski. Nazwa ta miała odzwierciedlać podobieństwo kroju ornatu do małych domków w buszu, które posiadały jedynie otwór u góry, służący jako okno lub komin. Należy zwrócić uwagę, że jeszcze we Francji w VII wieku phaenuli używali zarówno świeccy, jak i duchowni. Przykładem tego może być św. Fulgencjusz (†533), który po wyborze na biskupa nosił te same szaty, gdy był w stanie laikatu. Również św. Cezary arelateński († 540) chodził po mieście w ornacie, aczkolwiek, udając się na nabożeństwa, przywdziewał ornat bardziej bogato zdobiony ${ }^{13}$.

Pierwotnie ornat miał kształt dzwonu, z wycięciem na głowę u góry. Krój był równy z obu stron, całkowicie zamknięty i sięgający do kostek. Prezbiter, ubierając tego typu ornat zwany „dzwonowatym”, zbierał fałdy materiału na ramionach ${ }^{14}$. Ich ciężkość powodowała ograniczanie

${ }^{10}$ Por. L. Żarnowiecki, Szaty liturgiczne w pierwszych pięciu wiekach Kościoła, „Przegląd Katolicki” 8 (1900), s. 117; C. S. Keener, Komentarz historyczno-kulturowy do Nowego Testamentu, red. K. Bardski, W. Chrostowski, Warszawa 2000, s. 488.

11 Por. K. Konecki, dz. cyt., s. 57.

12 A. Nowowiejski, dz. cyt., s. 254-255.

13 Por. tamże, s. 220-221.

${ }^{14}$ Mozaika sięgająca V w. z bazyliki św. Ambrożego z Mediolanu, przedstawia świętego biskupa ubranego w phaenula. Dzieło może być uważane za najstarsze świadectwo przyjęcia tej szaty jako oficjalnego stroju używanego podczas liturgii. Por. 
ruchów celebransa, dlatego z czasem przyszywano na ramionach bogato zdobione sznury, którymi podpinano boki ornatu ${ }^{15}$. Głównym materiałem, z którego wykonywano najstarsze ornaty, była wełna i płótno, a co za tym idzie ich kolor zazwyczaj biały, szary lub szaro-brązowy odpowiadał naturalnej barwie płótna lub wełny. Zresztą do IX wieku nie spotyka się rozróżnienia kolorów w liturgii. Dopiero w VIII/IX wieku do wykonania ornatów używanych przez biskupów zaczęto sprowadzać droższe tkaniny z Bizancjum, Egiptu i Arabii w rozmaitych odcieniach, m.in. ciemnożółtym czy żółto-zielonym. Niekiedy na dzianinach można dostrzec vestes litteratae - litery, monogramy dość pokaźnych rozmiarów. Przeważnie miały one formę greckich minuskuł T, X, I, $\Gamma, H$. Niestety, nie wiadomo, co oznaczały owe litery znajdujące się na materiałach. Można przypuszczać, że były znakami warsztatów tkackich lub inicjałami mozaistów. Obok wspomnianych liter na starożytnych bizantyjskich mozaikach można dostrzec tzw. gammadje. Był to rodzaj krzyżyków złożonych z czterech greckich liter $\Gamma\left({ }_{7}\right)^{16}$. Na motywach zdobniczych (VI-XII w.) widnieją również bajeczne zwierzęta otoczone roślinami, bądź figury geometryczne. W kulturze Grecji i Cesarstwa Bizancjum stosowano małe koła, w których haftowano złote greckie krzyżyki. Symbolizowało to okrąg ziemi, w który wpisany jest chrześcijański Krzyż zwycięstwa Chrystusa. Do częstych

V. Lombardo, La casula di S. Apollinare a Ravenna: una lettura iconologica, w: Omnia parata. Le vesti liturgiche tra passato, presente e futuro, red. L. Palmeri, C. Piro, M. Vitella, Paceco 2006, s. 19. Przykładem mogą być szaty ukazane na mozaikach Rawenny z bazylik Sant’Apollinare in Classe (VI w.) oraz San Vitale (VI w.). W dolnej części absydy Sant’Apollinare in Classe, pomiędzy oknami widnieją czterej biskupi Rawenny: Ursicino, Orso, Severo, Ecclesio, ubrani w białą tunikę, paliusz - symbol jedności z Rzymem oraz ornat jednolitego koloru. Wyjątek stanowi przedstawienie św. Apolinarego w centrum absydy ubranego w białą tunikę, paliusz oraz phaenula koloru ciemnoczerwonego z odcieniem fioletu przyozdobiony motywem złotych pszczół, symbolu mądrości i elokwencji świętego. Ten sam motyw phaenula pojawia się w bazylice San Vitale w osobach biskupa Ecclesio oraz biskupa Massimiana. Por. C. Rizzardi, Il mosaico a Ravenna ideologia e arte, Bologna 2013, s. 152-155.

15 Por. G. Recelj, Prawo i liturgia. Nieco o szatach liturgicznych (krój, tkaniny i zdobnictwo), „Ateneum Kapłańskie” 25 (1930), s. 366.

${ }_{16}$ Por. B. Sztyber, Średniowieczne ornaty z przedstawieniami maryjnymi w Muzeum Narodowym w Gdańsku, „Universitas Gedanensis” 8 (1992), s. 60; A. Nowowiejski, dz. cyt., s. $222-228$. 
wzorów na starożytnych tkaninach należały lwy, które podkreślały godność celebransa, jego znaczenie i występowały jako jego obrońcy; gryfy, z ciałem zwierzęcia czworonożnego ze skrzydłami, szponami i głową orła. Motyw orła na szatach liturgicznych miał na celu „napomnienie, że duch jego (celebransa) przy spełnianiu Najświętszej Ofiary na skrzydłach modlitwy ma się wznosić do rzeszy nadzmysłowych, niebieskich, tak jak młody orzeł na silnych skrzydłach podąża do nieba”. Wszystkie postaci zoomorficzne są zwykle zwrócone ku sobie, w pozie walki, zwierzęta większe, takie jak lamparty czy lwy, są związane łańcuchem. Jeśli chodzi o motywy roślinne, na tkaninach pojawiają się kiery, karo, piki i trefle znane $\mathrm{z}$ dzisiejszych kart do gry. Na dzianinach produkowanych na terenie Grecji i Bizancjum pojawiają się sceny rodzajowe ze Starego i Nowego Testamentu ${ }^{17}$. Do wykonania ornatów biskupich od IV wieku stosuje się jedwab. Od XI wieku ornat zdobi się złotą taśmą rozwidlającą się przy szyi, zwaną aurifrisium. Pierwotnie zadaniem owego pasa miało być maskowanie szwów $\mathrm{w}$ materiale. $\mathrm{Z}$ czasem szerokie pasy płótna na ornatach stały się prawdziwymi wytworami sztuki zdobniczej ${ }^{18}$. Od VII wieku ornaty przybierają jeszcze większe rozmiary, a wycięcie na głowę ma formę kwadratu, spinanego sznurkiem lub agrafką. W okresie romańskim ornaty miały obszerny kształt, bez rękawów, oraz wykonywane były z lekkich i miękkich tkanin. W omawianym okresie pojawiały się ornamenty roślinne, zwierzęce lub geometryczne. W XII wieku coraz częściej pojawiają się na ornatach cenne złote pasy w postaci wstążek zwane orfrois. Z czasem (ok. XI w.) do zdobienia ornatów zaczęto używać złota, srebra, a nawet drogocennych kamieni i pereł. Ta przesadność w ornamentyce spowodowała, że bogato zdobione ornaty nie były używane ze względu na ciężar uniemożliwiający ich założenie, a tym bardziej sprawowanie czynności liturgicznych ${ }^{19}$.

W gotyku aż do XV wieku ornat zachowywał kształt dzwonu. Jednakże z powodu bogatych i ciężkich zdobień, zaczęto zmniejszać powierzchnię ornatu. $Z$ początków wycięcie w materiale sięgało łokci, tak że

17 Por. A. Nowowiejski, dz. cyt., s. 11-14.

18 Por. S. Piccolo Paci, dz. cyt., s. 316.

19 Por. A. Nowowiejski, dz. cyt., s. 222-228; B. Sztyber, Średniowieczne ornaty $z$ przedstawieniami maryjnymi, s. 60-61. 
przód i tył ornatu zakończony ostro spadał aż do ziemi. Z czasem wycięcia sięgały coraz wyżej, aż do ramion, przy czym skracano dół ornatu, kończąc go linią prostą. Jeśli chodzi o zdobnictwo, to dopiero w XV wieku orfois, zaczęto powiększać, a na ich płaszczyznach przedstawiano obrazy biblijne, postaci świętych, a nawet emblematy heraldyczne. W okresie odrodzenia ornaty posiadały jeszcze długi i fałdzisty tył. Z tego powodu ceremoniał biskupi przewidywał podnoszenie przez diakona ornatu podczas podniesienia ${ }^{20}$.

Pod koniec XVI wieku na południu kontynentu na ornatach zaczynają się pojawiać krótkie pasy, które wraz z biegnącą wzdłuż kolumną tworzyły rodzaj litery T. Natomiast na północy na ornaty z przodu i z tyłu przyszywano wstęgi w kształcie litery $\mathrm{Y}^{21}$. Od tego też wieku ustalił się kształt ornatu zbliżony do wydłużonego prostokąta o zaokrąglonych dłuższych bokach ${ }^{22}$. Tego typu ornat zyskał nazwę gotyckiego, chociaż z historycznym okresem gotyku nie miał nic wspólnego. W wiekach XIII-XV desenie na tkaninach przedstawiają typ saraceński. Głównymi motywami były znane już „bestiarium” wpisane w koła umieszczone na różnokolorowych paskach. Na pasach haftowano motywy pochodzące z islamu, takie jak półksiężyc, gwiazdy, kokardki, a nawet krótkie frazy wyjęte z Koranu. Między XIII a XIV wiekiem pojawiają się nowe tkaniny wykorzystywane do szycia szat liturgicznych, m.in. adamaszek, atłas, mora, brokat. Pod wpływem myśli średniowiecznej, według której dzieło sztuki tworzy się na większą chwałę Boga, na szatach zamiast motywów roślinnych pojawiają się scenki rodzajowe z życia Chrystusa i Maryi. Na szczególną uwagę zasługuje motyw granatu, który przez kolejne wieki będzie niepodzielnie widniał na tkaninach szat liturgicznych. W swojej symbolice czerwony owoc granatu wyobrażał miłość, a liczne ziarenka jedność Chrystusa i ludzi ${ }^{23}$. Starożytni Grecy owocem granatu obdarowywali zwycięzcę zawodów, w kulturze chrześcijańskiej granat jest symbolem zwycięstwa Chrystusa ${ }^{24}$. XVI wiek charakteryzował się wypukłym haftem z dodatkiem pereł i półszlachetnych kamieni z dodatkiem złota. Cały

${ }^{20}$ Por. A. Nowowiejski, dz. cyt., s. 234-235. 145; S. Piccolo Paci, dz. cyt., s. 312.

21 Por. G. Recelj, dz. cyt., s. 366.

22 Por. M. Cynka, Ornat i dalmatyka, „Msza święta” 3 (2007), s. 11.

${ }^{23}$ Por. A. Nowowiejski, dz. cyt., s. 16-29.

24 Por. G. Recelj, dz. cyt., s. 369. 
bogaty haft na ornacie tworzył coś w rodzaju barwnej płaskorzeźby ${ }^{25}$. Wpływ renesansu na zdobnictwo ornatów odznaczył się zastosowaniem ornamentów klasycznych, takich jak: liść akantu oraz naturalistyczne kwiaty. Wraz z rozwojem sztuki renesansu na tkaninach pojawiają się motywy palmety, ostu i wazy z koroną ${ }^{26}$.

Kolejnym ważnym do podkreślenia momentem w historii rozwoju ornatu jest okres baroku i rokoka (koniec XVII i XVIII w.). Podobnie do budowli sakralnych i wyposażenia wnętrza świątyni ornaty charakteryzują się bogatą ornamentyką. Odpowiadające estetyce epoki oddziaływały swym pięknem i bogactwem. Zamiast małych wzorów pojawiają się duże ornamenty w kształcie bukietów i kwiatowych girland ${ }^{27}$. W okresie baroku zaczyna się szczególne zainteresowanie i wykorzystanie motywów roślinnych. „Stosowanie w sztuce sakralnej ornamentyki kwiatowej i roślinnej, oprócz dekorowania miało za zadanie pouczenie o miłosierdziu Bożym i nawoływanie do naśladowania cnót chrześcijańskich"28. Od XVII wieku ornat otrzymał formę gruszki, a z bogato pofałdowanej szaty zostały tylko dwa sztywne kawałki materiału zszyte ze sobą w górnej części ${ }^{29}$. Od XVIII wieku forma ornatu przybiera kształt skrzypiec ${ }^{30}$. Na ogół kościoły posiadały po kilka ornatów z przypisanymi do nich dodatkami w postaci stuły, manipularza, dalmatyki i welonu kielichowego. Choć traciły ducha religijnego, były wykonane $\mathrm{z}$ dużym poczuciem estetyki. $\mathrm{Z}$ powodu wykorzystywania drogiego materiału do ornamentyki, np. złota lub srebra,

${ }^{25}$ Por. T. Mańkowski, Polskie tkaniny i hafty XVI-XVIII wieku, w: Studia $z$ dziejów polskiego rzemiosła artystycznego, red. A. Wojciechowski, t. 2, Wrocław 1954, s. 3.

26 Por. G. Recelj, dz. cyt., s. 369.

27 Por. M. Zieleniok, Odnowa szat liturgicznych, w: Wprowadzenie do liturgii, red. F. Blachnicki, W. Schenk, R. Zielsko, Poznań-Warszawa-Lublin 1967, s. 568.

28 Por. P. P. Maniura, Ornamentyka kwiatowa na szatach liturgicznych, w: Kultura i sztuka w służbie eucharystii. Materiały sympozjum zorganizowanego w Opolu i Kamieniu Śląskim (5-6.03.1997) przez katedre liturgiki i hagiografii oraz zakłady muzyki kościelnej i sztuki sakralnej Wydziału Teologicznego Uniwersytetu Opolskiego z okazji 46. Międzynarodowego Kongresu Eucharystycznego we Wrocławiu, red. R. Pierskała, R. Pośpiech, Opole 1997, s. 169.

29 Por. A. Nowowiejski, dz. cyt., s. 147.

30 Por. S. Piccolo Paci, dz. cyt., s. 312. 
bardzo często szaty te stawały się łupem złodziei ${ }^{31}$. Zdarzało się, że na ornacie haftowano miniatury postaci fundatorów oraz ich herby. Z czasem zaczęto powracać do motywów religijnych. Przedstawiano nie tylko sceny bliblijne, postaci świętych, lecz także z niezwykłą dokładnością i precyzją haftowano sceny z życia i działalności Chrystusa, Matki Bożej oraz świętych. Pod koniec XVIII i na pocz. XIX wieku ornaty były wykonywane z kolumn pasów jedwabnych i litych używanych głównie przez szlachtę do przewiązywania żupanów ${ }^{32}$. W XIX wieku ograniczono się jedynie do nieudolnego naśladownictwa i kopiowania wzorów ${ }^{33}$. Przemysł włókienniczy i ilościowe wyrabianie szat liturgicznych spowodowały upadek ducha sztuki, a na szatach widnieją ornamenty niechrześcijańskie ${ }^{34}$.

W XIX wieku ornat przybrał postać szaty o szerokości odpowiadającej ramionom, w kształcie dwóch podłużnych części połączonych ze sobą na ramionach $\mathrm{z}$ uwzględnieniem otworu na głowę, zupełnie rozciętych po bokach, tak aby zapewnić pełną swobodę ruchów. Ornat ten był nazwany rzymskim, a w nazewnictwie potocznym - ornatem skrzypcowym. Wykonany był z drogocennych tkanin: adamaszku, atłasu, brokatu, aksamitu. W przedzie i tyle posiadał tzw. pretekstę, czyli haftowaną złotem i wielobarwnymi nićmi pionową wstęgę. Ornat skrzypcowy posiadał wiele odmian, m.in. francuską, rzymską, hiszpańską czy brazylijską, różniących się między sobą kształtem i rodzajem preteksty. Wzór ornatu skrzypcowego był najpopularniejszy i niezmienny aż do reformy Soboru Watykańskiego w 1968 roku $^{35}$.

31 Por. S. Litak, Parafie w Rzeczpospolitej w XVI-XVIII wieku. Struktura, funkcje społeczno-religijne i edukacyjne, Lublin 2004, s. 121-122.

32 Por. A. Nowowiejski, dz. cyt., s. 147-148; zob. A. Bender, Szaty liturgiczne to też dzieła sztuki. Wybrane przykłady z XVIII wieku w polskich zbiorach, „Liturgia Sacra” 17 (2011) nr 2, s. 403-415; A. Bender, Szaty liturgiczne z polskich pasów kontuszowych i tkanin naśladujaccych pasy kontuszowe. Stan i perspektywy badań, w: Architektura znaczeń: studia ofiarowane prof. Zbigniewowi Bani w 65. rocznice urodzin i $w$ 40-lecie pracy dydaktycznej, red. A. S. Czyż, J. Nowiński, M. Wiraszka, Warszawa 2011, s. 454-463.

33 Por. M. Zieleniok, dz. cyt., s. 568.

34 Por. S. Piccolo Paci, dz. cyt., s. 314.

35 Por. J. Zjawin, Słowniczek liturgiczny. Co to jest ornat?, „Przewodnik Katolicki” 40 (2007), s. 22. 


\section{DALMATYKA - GENEZA I ROZWÓJ SZATY DIAKONA}

Rozmaitość czynności wykonywanych podczas liturgii wymaga rozróżnienia pełniących je osób. Wspomniany ornat podczas sprawowania liturgii odróżnia biskupa lub prezbitera od diakona ubranego w dalmatykę wskazującą na jego funkcję podczas sprawowania liturgii. Dalmatyka (łac. dalmatica vestis - dalmatyńska szata) swoją nazwę zaczerpnęła z Dalmacji ${ }^{36}$, skąd za pośrednictwem Greków dotarła na terytorium Imperium Rzymskiego (II w. n.e.) jako uroczysta szata wierzchnia ${ }^{37}$. Początkowo była uważana za strój typowo kobiecy. Szybko jednak stała się strojem używanym przez arystokrację ${ }^{38}$. Była to luźna szata noszona bez przepasania z długimi rękawami, poszerzanymi u spodu. Na przedzie i tyle posiadała dwa przyszyte barwne pasy zwane clavi ${ }^{39}$. Do praktyki Kościoła przeszła z ceremoniału świeckiego ${ }^{40}$. S. Piccolo Paci zauważa, że dalmatyka była strojem silnie związanym z władzą cesarzy i władzą duchową. Używana podczas konsekracji cesarzy, stopniowo przeszła do ceremoniału papieskiego, prawdopodobnie za zgodą władzy świeckiej ${ }^{41}$.

Pierwsze wiadomości o dalmatyce pochodzą z opisu męczeństwa św. Cypriana (258 r.). Według tradycji, w dniu męczeństwa święty miał mieć na sobie lnianą tunikę, dalmatykę i bliżej nieokreślone ubranie wierzchnie podobne do ornatu. $Z$ powyższego opisu nie należy jednak wnioskować, że w tym okresie dalmatyka była szatą przeznaczoną do kultu chrześcijańskiego ${ }^{42}$. Dekret papieża Eutychjana (274-285) nakazywał pochówek męczenników w dalmatyce lub purpurowym colobium $^{43}$. W Rzymie od IV wieku dalmatyka stała się szatą liturgiczną właściwą dla

${ }^{36}$ Por. D. Bączkowski, Krótki wykład obrzędów Katolickiego Kościoła, [bmw., brw.], s. 21; S. Piccolo Paci, dz. cyt., s. 320.

37 Por. T. Gołgowski, Dalmatyka, w: Encyklopedia katolicka, t. 3, s. 982.

38 Por. S. Piccolo Paci, dz. cyt., s. 322.

39 Por. E. Szyller, Historia ubiorów, Warszawa 1960, s. 63; S. Piccolo Paci, dz. cyt., s. 322 .

${ }^{40}$ Por. T. Kwiecień, „Moda kapłańska”, czyli o liturgicznej szacie. Ornat i dalmatyka, „Przewodnik Katolicki” 5 (2004), s. 20.

${ }^{41}$ Por. S. Piccolo Paci, dz. cyt., s. 322.

${ }^{42}$ Por. L. Duchesne, Orgines du culte chrétien. Étude sur la liturgie latine avant charlemagne, Paris 1889, s. 368.

${ }^{43}$ Por. A. Nowowiejski, dz. cyt., s. 330. 
diakonów i biskupów. Papież św. Sylwester (314-335) ustanowił zwyczaj noszenia dalmatyki przez diakonów ${ }^{44}$. Z początku szata była zarezerwowana jedynie dla kościoła rzymskiego oraz dla tych, którym na jej noszenie zezwolił papież, np. papież Symmachus (498-514) wyraźnie zezwolił na używanie dalmatyki diakonom Cezarego z Arles, a papież św. Grzegorz Wielki (590-604) diakonom kościoła w Gap. Stosowanie jej na podstawie milczącego przyzwolenia utrwalało się powoli w całym świecie kultury chrześcijańskiej. Już na mozaikach z V wieku w Mediolanie i z VI wieku w Rawennie ${ }^{45}$ pojawia się dalmatyka. Od IX wieku zwyczaj noszenia dalmatyki był tak bardzo rozpowszechniony, że niektórzy z prezbiterów wdziewali dalmatykę pod ornat. Takim praktykom sprzeciwiała się Stolica Apostolska, która ostatecznie jeszcze przed XI wieku zezwoliła na noszenie dalmatyki kardynałom, opatom, aż w końcu pozostałym prezbiterom ${ }^{46}$. Początkowo dalmatyka jako szata liturgiczna była koloru białego, a jej nieodłączną ozdobą były clavi. Z podań Amalariusza Fortunatusa (X w.) możemy wnioskować, że owe ozdobne wstęgi koloru szkarłatnego były przyszywane z przodu i tyłu oraz biegły od szyi aż do samego spodu szaty. $\mathrm{Z}$ czasem wstęgi te przybrały kolor czarny lub fioletowy ${ }^{47}$. W Rzymie aż do XII wieku długość dalmatyki sięgała kostek, natomiast w okolicach przedalpejskich od XI wieku zaczęto ją skracać. Od tego też wieku zarówno biskupi, jak i kapłani zakładali dalmatykę pod ornat, podczas gdy staje się ona strojem właściwym diakona. W XVI wieku rękawy przybrały formę skrzydeł. W powolnym, lecz ciągłym rozwoju kroju dalmatyki, skracano jej długość. W XIII wieku wynosiła ok. 1,25-1,20 m w tym samym stopniu zmniejsza się szerokość, która w XVI wieku dochodzi do $0,50 \mathrm{~m}^{48}$. Od XIII wieku na dalmatykach pojawiają się zdobne kolumny, na których przedstawione są postaci świętych, oraz inne motywy zdobnicze podobnie jak w przypadku ornatów. Od XVIII wieku boki dalmatyki przybrały

${ }^{44}$ Por. E. Górski, Święcenia niższe $i$ wyższe. Studium liturgiczno-historyczne, Sandomierz 1954, s. 59.

${ }^{45} \mathrm{Na}$ mozaice w mauzoleum Galli Placydii (I poł. V w.) widnieje Chrystus Dobry Pasterz ubrany w długą dalmatykę z purpurowym płaszczem.

${ }^{46}$ Por. C. Callewaert, Sacris Erudiri. Fragmenta liturgica collecta a Monachis sancti Petri de Aldenburgo in Steenbrugge ne pereant, Steenburgge 1940, s. 219-220.

47 Por. A. Nowowiejski, dz. cyt., s. 332.

48 Por. C. Callewaert, dz. cyt., s. 220-221. 
formę otwartą tak, że odsłaniały całą postać. Rękawy stały się luźnymi kawałkami kwadratowych części materiału, z czasem dla wygody zaczęto je przymocowywać do ramion sznurkami lub wstążkami. Od XVI wieku dla ułatwienia wykonywania przez biskupa ruchów podczas sprawowania liturgii, dalmatyki, które zakładał pod ornat wykonywano z lekkiego materiału, o tej samej barwie co ornat ${ }^{49}$. Należy zwrócić uwagę na fakt praktyki noszenia dalmatyki przez biskupów nie tylko pod ornatem, jak to przedstawia wielu liturgistów, lecz także pod kapą. Dowodem na to są liczne zabytki sztuki malarstwa europejskiego ${ }^{50}$.

\section{KAPA - GENEZA I ROZWÓJ}

Kolejną z szat liturgicznych stosowanych w kulcie Kościoła Rzymskokatolickiego jest kapa. Swymi początkami sięga ona VIII-IX wieku i została zapożyczona od płaszcza kleryckiego lub zakonnego, który odróżniał się od pokrewnego mu płaszcza w kształcie ornatu dzwonowatego tym, że posiadał kaptur oraz rozcięcie $z$ przodu ${ }^{51}$. Noszono go szczególnie wtedy, kiedy sprawowano Mszę św. lub podczas procesji. Na dni świąteczne były przeznaczone peleryny świąteczne, wykonane $\mathrm{z}$ cennego materiału, czasami nawet z jedwabiu. Na pewno w X wieku kapa była już powszechnie używaną szatą liturgiczną. Posługiwali się nią kantorzy, dyrygenci chórów i śpiewacy, księża w czasie procesji przenoszenia relikwii i podejmowania wysokich dostojników, zebrani na synodzie biskupi, biskup, który konsekrował kościół itd. W poszczególnych wypadkach, jak np. przy konsekracjach kościołów, przejściach z sakramentem do chorego, jej użycie wówczas było jeszcze nieokreślone, jednak i w nich, najpóźniej pod koniec XI w., sprawę rozstrzygnięto ostatecznie na korzyść kapy. $\mathrm{W}$ okresie romańskim kapa przybrała kształt rozciągniętego materiału

49 Por. A. Nowowiejski, dz. cyt., s. 340-344.

${ }^{50}$ Por. T. Kruszyński, Dalmatyka i tunicella obok kapy $w$ stroju pontyfikalnym, „Przegląd Teologiczny” 9 (1928), s. 269.

${ }^{51}$ Por. K. Konecki, dz. cyt., s. 60; M. Straszewicz, Kapa, w: Encyklopedia katolicka, t. 8, s. 642; Niektórzy liturgiści wywodzą współczesną kapę od greckiego i rzymskiego płaszcza z kapturem (lacerna), chroniącego przed deszczem, por. G. Polak (red.), Struktura Mszy świętej, w: Kolekcja Jan Paweł II - 2000 lat chrześcijaństwa, 20 (2001) 45, s. 15. 
wzdłuż ciała, a jedyną ozdobą były clavi spadające od szyi z przodu, po jednej z każdej strony. Kaptur, który pierwotnie miał za zadanie chronić przed wpływami atmosferycznymi, pozostał w swej pierwotnej formie, głównie jako ozdoba. U spodu kapy były umieszczane frędzle lub dzwoneczki. Dla podtrzymania kapy u góry używano klamry. $Z$ reguły owe klamry były dziełami sztuki złotniczej, wysadzane drogocennymi kamieniami. W gotyku klamry osiągnęły apogeum zdobnictwa. Umieszczano wówczas na nich całe postaci świętych, obrazy Trójcy Świętej, Adama i Ewy lub inne sceny biblijne. Zdarzało się, że widniały na nich herby lub postaci samych ofiarodawców cennej szaty. Brzegi klamry otaczano wieńcem pereł. W XIV wieku na zdobnictwo kapy ogromny wpływ miał zwyczaj kupowania przez kanoników kap, w których uczestniczyli podczas liturgii. Stąd we wzornictwie tak duża różnorodność. Z racji obszernej powierzchni materiału hafty odznaczały się nieraz przesadnym wzornictwem. Treść owych haftów to sceny biblijne, prorocy, aniołowie z instrumentami muzycznymi, kadzielnicami, jak również herby rodów kanoników. Z powodu ogromnej ilości haftu nazwano je kapami obrazowymi. Kaptur w omawianym okresie przypominał tarczę ze złota, którą często można było odpinać za pomocą złotych guzików, aby ozdobić nim inną kapę. Z czasem kaptur z trójkątnego przybrał kształt półkola i zajmował większą część tyłu. Od ok. XV wieku otrzymał on kształt przygiętego łuku. W XVI wieku zupełnie zaniknął spiczasty kształt łuku tarczy, który tworzył na dole półkole, a w baroku owal ${ }^{52}$.

Należy jeszcze wspomnieć o dwóch rodzajach kap. Pierwsza używana przez biskupów (capa magna) od czasu odrodzenia oraz drugiej używanej podczas koronacji cesarzy i królów. Co do kapy biskupiej, capa magna była bardzo obszerną szatą, tak, że jej tren musiano nosić. Jeszcze krótko przed reformą Soboru Watykańskiego II papież przywdziewał na siebie tak długą kapę, że jej tren zasłaniał stopnie papieskiego tronu. Co do stroju króla podczas koronacji, używał on obok alby i dalmatyki właśnie kapy. Aby ukazać splendor uroczystości koronacyjnych owe kapy były dziełami sztuki hafciarskiej i złotniczej ${ }^{53}$.

\footnotetext{
${ }^{52}$ Por. A. Nowowiejski, dz. cyt., s. 307-312.316.

${ }^{53}$ Por. T. Kruszyński, dz. cyt., s. 227.
} 


\section{ZABYTKOWE SZATY LITURGICZNE BAZYLIKI MNIEJSZEJ W SIERADZU ${ }^{4}$}

Przechowywane na co dzień w parafii pw. Wszystkich Świętych w Sieradzu zabytkowe szaty liturgiczne, są świadectwem umiłowania liturgii na ziemi sieradzkiej należącej do diecezji włocławskiej. Stan przechowywania i pieczę nad tym wyjątkowym dziedzictwem kultury od 1 maja 2006 roku został powierzony proboszczowi parafii ks. doktorowi Marianowi Bronikowskiemu. Pośród licznych prac renowacyjnych prowadzonych przy świątyni, która od 19 marca 2018 roku decyzją papieża Franciszka nosi tytuł Bazyliki Mniejszej, szaty liturgiczne przechowywane w zakrystii kościoła zostały przeniesione do domu parafialnego oraz ponownie skatalogowane przez dr Ewę Andrzejewską.

$\mathrm{W}$ posiadaniu parafii znajdują się ornaty w kolorach białym, zielonym, czerwonym, fioletowym i różowym o tzw. kroju rzymskim, wykonane z różnych materiałów pokrytych haftem o motywach roślinnych. Interesującym elementem są napisy wykonane odręcznie na podszewkach szat lub małe karteczki przyszyte $\mathrm{z}$ tyłu ornatu wykonane w większości przez ks. Walerego Pogorzelskiego, proboszcza sieradzkiej parafii w latach 1923-1941 świadczące o ich niepowtarzalnej historii.

1. Ornat biały wykonany $\mathrm{w}$ stylu regencji, rokoko pochodzi $\mathrm{z}$ lat 30. XVII wieku (boki datowane na lata 50.-60. XVIII w.). Zabytek został wpisany do rejestru zabytków 2.03.1974 roku, B/338/124/poz. $145^{55}$.

2. Ornat biały w stylu barokowym, datowany na 1 . tercję XVIII wieku $\mathrm{z}$ gruntownie przeprowadzoną restauracją w latach 20. lub 30. $\mathrm{XX}$ wieku. Ornat został wpisany do rejestru zabytków z datą 2.03.1974 r., B/338/124/poz. $137^{56}$. Prawdopodobnie o szacie wspomina ks. Walery Pogorzelski w książce zadedykowanej Sieradzowi: „ornat biały ze słupem

${ }^{54} \mathrm{~W}$ artykule zostają wymienione szaty posiadające kartę ewidencyjną zabytku ruchomego przechowywaną w Archiwum Parafii Wszystkich Świętych w Sieradzu.

${ }^{55}$ Por. Archiwum Parafii Wszystkich Świętych w Sieradzu [APWWŚS], E. Andrzejewska, Karta ewidencyjna zabytku ruchomego [KEZR], Ornat biały, Sieradz, 2011.07.22 [ms.]

${ }^{56}$ Por. APWWŚS, E. Andrzejewska, dz. cyt. 
złotem haftowanym"57. W posiadaniu parafii jest inny, bardzo podobny biały ornat, na którego pretekście z tyłu w dolnej części widnieje wyhaftowany herb ks. W. Pogorzelskiego. Nie posiada on niestety karty ewidencyjnej zabytku ruchomego.

3. Orant w kolorze białym w stylu barokowym datowany na ok. połowę XVIII wieku z gruntowną naprawą w 1931 roku. Ornat został wpisany do rejestru zabytków z datą 2.03.1974 roku, B/338/124/poz. $147^{58}$.

4. Ornat biały w stylu barkowym datowany na ok. połowę XVIII wieku. Ornat został wpisany do rejestru zabytków z datą 2.03.1974 roku, B/338/124/poz. $144^{59}$.

5. Ornat zielony w stylu renesansowym lub barokowym. Datowany na karcie zabytków w rubryce „czas powstania” na 2. połowę XVI wieku; 2. lub 3. ćwierć XVII wieku, galony - kon. XVIII wieku. Ornat został wpisany do rejestru zabytków z datą 2.03.1974 roku, B/338/124/poz. 15060.

6. Ornat zielony w stylu barkowym został wykonany w połowie XVIII wieku. Na karcie ewidencyjnej zabytku nie zostały umieszczone data i numer ewidencyjny ${ }^{61}$.

Pokaźną kolekcję stanowią ornaty czerwone.

1. Ornat czerwony w stylu renesansowym pochodzący z 4 ćwierci XV wieku (galony z końca XVIII w.). Ornat został wpisany do rejestru zabytków z datą 2.03.1974 roku, B/338/124/poz. $139^{62}$.

57 W. Pogorzelski, Sieradz, Włocławek 1927, s. 27.

${ }_{58}$ Por. APWWŚS, E. Andrzejewska, KEZR, Orant biały.

59 Por. tamże.

${ }^{60}$ Por. APWWŚS, E. Andrzejewska, KEZR, Orant zielony, Sieradz, 2011.07.22 [ms.].

${ }_{61}$ Por. APWWŚS, E. Andrzejewska, KEZR, Orant zielony.

${ }^{62}$ Por. APWWŚS, E. Andrzejewska, KEZR, Orant czerwony, Sieradz, 2011.07.22 [ms.]. 
2. Ornat czerwony w stylu regencji z 2 dekady XVIII wieku. Obiekt został wpisany do rejestru zabytków z datą 2.03.1974 roku, B/338/124/ poz. $148^{63}$.

3. Ornat czerwony w stylu barokowym datowany na 1. połowę XVII wieku (tkanina), XVII wiek (galon). Obiekt został wpisany do rejestru zabytków z datą 2.03.1974 roku, B/338/124/poz. $141^{64}$.

4. Ornat czerwony w stylu barokowym z końca XVII lub 1. tercji XVIII wieku. Obiekt został wpisany do rejestru zabytków z datą 2.03.1974 roku, B/338/124/poz. $140^{65}$.

5. Orant czerwony w stylu klasycystycznym z 4. ćwierci XVIII wieku. Ornat został wpisany do rejestru zabytków z datą 2.03.1974 roku. B/338/124/poz. $151^{66}$.

6. Ornat czerwony $\mathrm{z}$ herbem Ogończyk ${ }^{67} \mathrm{w}$ stylu rokoko, datowany na lata 60. XVIII wieku (galony sięgają XVII w.), został wpisany do rejestru zabytków z datą 2.03.1974 roku, B/338/124/poz. $142^{68}$.

${ }^{63}$ Por. APWWŚS, E. Andrzejewska, KEZR, Orant czerwony.

${ }^{64}$ Por. tamże.

${ }^{65}$ Por. APWWŚS, E. Andrzejewska, KEZR, Orant czerwony ze stuła, Sieradz, 2011.07.22 [ms.]

${ }^{66}$ Por. APWWŚS, E. Andrzejewska, KEZR, Orant czerwony.

${ }^{67}$ Jak podaje R. Bogusławski, przypuszczalnie herb jest związany z osobą zamieszkującą Sieradz, lub pełniącą urząd na jego terenie. „Spośród przedstawicieli rodu Ogończy [...] najbardziej prawdopodobnymi kandydatami są: 1) Marcin Murzynowski h. Ogończyk, zmarły w 1787 r., dziedzic dóbr Dębołęka [...], 2) Feliks Murzynowski h. Ogończyk, urodzony ok. 1765, sędzia pokoju, dziedzic Dębołęki, 3) Jan Mniewski h. Ogończyk, zmarły w 1792 r., wojski sieradzki, dziedzic Wrząsawy i Czarnyża. W tamtym czasie żyli też inni zamożni przedstawiciele rodzin szlacheckich Ziemi Sieradzkiej pieczętujących się herbem Ogończyk - Wolscy vel Dobruchowscy, Wysoccy, Skorzewscy, Siewierscy, Mikołajewscy i inni. Jednak ich związek z Sieradzem był naszym zdaniem mniejszy od trzech wymienionych wcześniej i co za tym idzie, prawdopodobieństwo fundowania przez nich ornatu także mniejsze choć nie wykluczone”, R. Bogusławski, Wartości zabytkowe wybranych najstarszych szat liturgicznych kościoła farnego w Sieradzu, „Na Sieradzkich Szlakach” 3/127 (2017) XXXII, s. 53-54.

${ }^{68}$ Por. APWWŚS, E. Andrzejewska, KEZR, Orant czerwony z herbem Ogończyk, Sieradz, 2011.07.22 [ms.]. 
7. Ornat czerwony w stylu renesansu lub klasycystycznym datowany na koniec XV wieku i 4. ćwierć XVIII wieku. Obiekt nie posiada numeru rejestru ${ }^{69}$.

Poza wyżej wymienionymi obiektami w kolekcji znajdują się dwa ornaty fioletowe i jeden różowy.

1. Ornat fioletowy w stylu renesansowym lub barokowym. Datacja tkaniny od XV wieku do pocz. XVII wieku, galony datowane na koniec XVIII wieku. Ornat został wpisany do rejestru zabytków z datą 2.03.1974 roku, B/338/124/poz. $146^{70}$.

2. Ornat fioletowy w stylu późnego rokoka, datowany na lata 60 . XVIII wieku ${ }^{71}$. Obiekt nie posada numeru rejestru.

3. Ornat różowy w stylu regencji datowany na 2.-3. dekadę XVIII wieku (tkanina boków). Obiekt został wpisany do rejestru zabytków z datą 2.03.1974 roku, B/338/124/poz. $149^{72}$.

Kolekcję dopełniają dwa komplety dalmatyk białych. Pierwszy $\mathrm{z}$ nich datowany na lata 20. lub 30. XX wieku, jest parą do ornatu białego ${ }^{73}$ [B/338/124/poz. 137]. Dalmatyki są wpisane do rejestru zabytków z datą 2.03.1974 roku. B/338/124/poz. $152^{74}$. Drugi komplet datowany na lata 1750-1760 z niebieską podszewką, na której widnieje napis „MEMENTO/ STANISLAI SACERDOTIS E. C. S./ Año Dñi 1785 D. 3tio 8bris". Obiekty zostały wpisane do rejestru zabytków z datą 2.03.1974 roku, B/338/124/ poz. $153^{75}$.

${ }^{69}$ Por. APWWŚS, E. Andrzejewska, KEZR, Orant czerwony.

${ }^{70}$ Por. APWWŚS, E. Andrzejewska, KEZR, Orant fioletowy, Sieradz, 2011.07.22 [ms.]

${ }^{71}$ Por. APWWŚS, E. Andrzejewska, KEZR, Orant fioletowy.

72 Por. APWWŚs, E. Andrzejewska, KEZR, Orant różowy, Sieradz, 2011.07.22 [ms.].

${ }^{73} \mathrm{~W}$ niniejszym artykule znajdującym się pod numerem 2.

74 Por. APWWŚS, E. Andrzejewska, KEZR, Para dalmatyk białych $z$ trzema stułami, Sieradz, 2011.07.22 [ms.].

75 Por. APWWŚS, E. Andrzejewska, KEZR, Para dalmatyk białych, Sieradz, 
Oprócz wspomnianych wyżej obiektów została wpisana do rejestru zabytków z datą 2.03.1974 roku B/338/124/poz. 155 biała kapa z 1. tercji XVIII wieku z gruntowną naprawą przeprowadzoną w latach 20. lub 30. $\mathrm{XX}$ wieku. Interesujące jest zapięcie kapy wykonane ze sprzączki pasa pułkownikowskiego $\mathrm{w}$ kształcie prostokąta o wymiarach $7,4 \times 10,5 \mathrm{~cm}$, wykonanego z pozłacanego stopu miedzi. Jego dekorację stanowi orzeł w koronie zamkniętej z mieczem i tarczą, na której figuruje monogram króla Stanisława Augusta Poniatowskiego „SAR”76.

\section{ZAKOŃCZENIE}

$\mathrm{Na}$ przestrzeni wieków zmieniająca się moda wywarła wpływ również na kształt szat liturgicznych. Choć ich geneza pozostaje wciąż przedmiotem dyskusji, to historia rozwoju jest imponująca. Od prostych szat niewiele odróżniających się, używanych na co dzień, po prawdziwe dzieła sztuki, podkreślające wyjątkowość momentu celebracji. Zbiór zabytkowych szat przechowywanych przy Bazylice Mniejszej w Sieradzu, wykonanych $\mathrm{z}$ drogocennych tkanin i ozdobionych haftem o motywach roślinnych, może stanowić przykład umiłowania liturgii. Wiedza o ewolucji ornatu, dalmatyki czy kapy, technikach wykonania i materiałach pokrótce podjęty w artykule mogą stanowić przyczynek do ich lepszej ochrony i traktowania na równi z innymi zabytkami ruchomymi. Niestety, w przeważającej mierze szaty liturgiczne są wciąż pomijane podczas różnych prac renowacyjnych prowadzonych przy świątyniach, a co za tym idzie, $\mathrm{z}$ roku na rok te wyjątkowe dzieła wykonane z kruchych materiałów ulegają powolnej destrukcji.

2011.07.22 [ms.]. Do zapięcia dalmatyki został wykorzystany złocony metalowy guzik, na którym figuruje popiersie ubranego w mundur generalski z czakiem na głowie księcia Józefa Poniatowskiego, por. R. Bogusławski, Wartości zabytkowe, s. 55.

${ }^{76}$ Por. APWWŚS, E. Andrzejewska, KEZR, Kapa liturgiczna biała, Sieradz, 2011.07.22 [ms.]; R. Bogusławski, Wartości zabytkowe, s. 52-53. 


\section{BIBLIOGRAFIA}

Archiwum Parafii Wszystkich Świętych w Sieradzu [APWWŚS], E. Andrzejewska, Karta ewidencyjna zabytku ruchomego [KEZR], Ornat biały, Sieradz, 2011.07.22 [ms.].

APWWŚS, E. Andrzejewska, KEZR, Kapa liturgiczna biała, Sieradz, 2011.07.22 [ms.].

APWWŚS, E. Andrzejewska, KEZR, Orant czerwony, Sieradz, 2011.07.22 [ms.].

APWWŚS, E. Andrzejewska, KEZR, Orant fioletowy, Sieradz, 2011.07.22 [ms.].

APWWŚS, E. Andrzejewska, KEZR, Orant biały, Sieradz, 2011.07.22 [ms.].

APWWŚS, E. Andrzejewska, KEZR, Orant czerwony z herbem Ogończyk, Sieradz, 2011.07.22 [ms.].

APWWŚS, E. Andrzejewska, KEZR, Orant czerwony ze stuła, Sieradz, 2011.07.22 [ms.].

APWWŚS, E. Andrzejewska, KEZR, Orant czerwony, Sieradz, 2011.07.22 [ms.].

APWWŚS, E. Andrzejewska, KEZR, Orant różowy, Sieradz, 2011.07.22 [ms.].

APWWŚS, E. Andrzejewska, KEZR, Orant zielony, Sieradz, 2011.07.22 [ms.].

APWWŚS, E. Andrzejewska, KEZR, Ornat biały ze stuła, Sieradz, 2011.07.22 [ms.].

APWWŚS, E. Andrzejewska, KEZR, Para dalmatyk białych z trzema stułami, Sieradz, 2011.07.22 [ms.].

APWWŚS, E. Andrzejewska, KEZR, Para dalmatyk białych, Sieradz, 2011.07.22 [ms.].

Bączkowski D., Krótki wykład obrzędów Katolickiego Kościoła, [bmw., brw.].

Bender A., Szaty liturgiczne to też dzieła sztuki. Wybrane przykłady z XVIII wieku w polskich zbiorach, „Liturgia Sacra” 17 (2011) nr 2, s. 403-415.

Bender A., Szaty liturgiczne z polskich pasów kontuszowych i tkanin naśladujących pasy kontuszowe. Stan i perspektywy badań, w: Architektura znaczeń: studia ofiarowane prof. Zbigniewowi Bani w 65. rocznice urodzin i $w$ 40-lecie pracy dydaktycznej, red. A. S. Czyż, J. Nowiński, M. Wiraszka, Warszawa 2011, s. 454-463.

Bogusławski R., Wartości zabytkowe wybranych najstarszych szat liturgicznych kościoła farnego w Sieradzu, „Na Sieradzkich Szlakach” 3/127 (2017) XXXII, s. 51-57.

Boucher F., Historia mody. Dzieje ubiorów od czasów prehistorycznych do końca XX wieku, Warszawa [brw.].

Callewaert C., Sacris Erudiri. Fragmenta liturgica collecta a Monachis sancti Petri de Aldenburgo in Steenbrugge ne pereant, Steenburgge 1940.

Cynka M., Ornat i dalmatyka, „Msza święta” 3 (2007), s. 11-12.

Duchesne L., Orgines du culte chrétien. Étude sur la liturgie latine avant charlemagne, Paris 1889.

Głowa W., Posługi i funkcje w zgromadzeniu liturgicznym, w: Mszał księga życia chrześcijańskiego, red. B. Nadolskiego, Poznań 1986, s. 313-331.

Gołgowski T., Dalmatyka, w: Encyklopedia katolicka, t. 3, s. 982-983.

Górski E., Święcenia niższe i wyższe. Studium liturgiczno-historyczne, Sandomierz 1954.

Gutkowska-Rychlewska M., Historia ubiorów, Wrocław-Warszawa-Kraków 1968.

Keener C. S., Komentarz historyczno-kulturowy do Nowego Testamentu, red. K. Bardski, W. Chrostowski, Warszawa 2000. 
Komornicka A. M., Zagadki z Biblii, Tradycji i Kultury chrześcijańskiej, t. 1, Marki 2000.

Konecki K., Pochodzenie i rozwój szat liturgicznych, „Anamnesis” 13 (1997/1998), s. 52-62.

Kruszyński T., Dalmatyka i tunicella obok kapy w stroju pontyfikalnym, „Przegląd Teologiczny" 9 (1928), s. 269-280.

Kwiecień T., „Moda kapłańska”, czyli o liturgicznej szacie. Ornat i dalmatyka, „Przewodnik Katolicki” 5 (2004), s. 20-21.

Litak S., Parafie w Rzeczpospolitej w XVI-XVIII wieku. Struktura, funkcje społeczno-religijne i edukacyjne, Lublin 2004.

Lombardo V., La casula di S. Apollinare a Ravenna: una lettura iconologica, w: Omnia parata. Le vesti liturgiche tra passato, presente e futuro, red. L. Palmeri, C. Piro, M. Vitella, Paceco 2006, s. 19-25.

Maniura P.P., Ornamentyka kwiatowa na szatach liturgicznych, w: Kultura i sztuka $w$ stużbie eucharystii. Materiały sympozjum zorganizowanego w Opolu i Kamieniu Śląskim (5-6.03.1997) przez katedrę liturgiki i hagiografii oraz zakłady muzyki kościelnej i sztuki sakralnej Wydziału Teologicznego Uniwersytetu Opolskiego z okazji 46. Międzynarodowego Kongresu Eucharystycznego we Wrocławiu, red. R. Pierskała, R. Pośpiech, Opole 1997, s. 167-176.

Mańkowski T., Polskie tkaniny i hafty XVI-XVIII wieku, w: Studia z dziejów polskiego rzemiosła artystycznego, red. A. Wojciechowski, t. 2, Wrocław 1954.

Nowowiejski A., Wykład liturgii Kościoła Katolickiego, t. 2, Warszawa 1902.

Piccolo Paci S., Storia delle vesti liturgiche. Forma, immagine e funzione, Milano 2008.

Polak G. (red.), Struktura Mszy świętej, w: Kolekcja Jan Paweł II - 2000 lat chrześcijaństwa, 20 (2001) 45, s. 13-18.

Recelj G., Prawo i liturgia. Nieco o szatach liturgicznych (krój, tkaniny i zdobnictwo), „Ateneum Kapłańskie” 25 (1930), s. 365-371.

Rizzardi C., Il mosaico a Ravenna ideologia e arte, Bologna 2013.

Sorrentino A., Sztuka przewodniczenia celebracjom liturgicznym. Praktyczne sugestie dla kapłanów, Kraków 2001.

Straszewicz M., Kapa, w: Encyklopedia katolicka, t. 8, s. 641-642.

Sztyber B., Średniowieczne ornaty z przedstawieniami maryjnymi w Muzeum Narodowym w Gdańsku, „Universitas Gedanensis” 8 (1992), s. 54-78.

Szyller E., Historia ubiorów, Warszawa 1960.

Pogorzelski W., Sieradz, Włocławek 1927.

Wilpert J., Le pitture nelle catacombe romane, t. 1, Roma 1903.

Zieleniok M., Odnowa szat liturgicznych, w: Wprowadzenie do liturgii, red. F. Blachnicki, W. Schenk, R. Zielsko, Poznań-Warszawa-Lublin 1967, s. 566-579.

Zjawin J., Słowniczek liturgiczny. Co to jest ornat?, „Przewodnik Katolicki” 40 (2007), s. 22. Żarnowiecki L., Szaty liturgiczne w pierwszych pięciu wiekach Kościoła, „Przegląd Katolicki” 8 (1900), s. 116-119. 